\title{
THE EFFECT OF AMBIENT TEMPERATURE ON HUMAN STRENGTH
}

\section{VINAYAK MARATHE, SHRIRAM SANE, VARSHA KARANDIKAR \& AMOL MATE}

Vishwakarma Institute of Technology, Bibvewadi, Pune, Maharashtra India

Savitribai Phule Pune University, Pune, India

\begin{abstract}
Impact of environmental conditions like temperature is usually not considered in the measurement of work content analysis. However, to ensure healthy work conditions, it is imperative that studies on the effects of heat and cold stress on workers' capacity are carried out and existing guidelines on working capacity be suitably modified. In this study, the effect of heat stress on the physical strength of subjects measured in terms of average push/pull/ pedal/ grip force applied over 30 seconds was recorded. In dry bulb temperature studies, it was found that subjects showed a maximum strength at $20^{\circ} \mathrm{C}$ or $25^{\circ} \mathrm{C}$ and a $30 \%$ and $35 \%$ drop in strength was observed at $5^{\circ} \mathrm{C}$ and $40^{\circ} \mathrm{C}$ respectively. In case of wet bulb globe temperature (WBGT), the maximum strength was recorded between $13^{\circ} \mathrm{C}$ to $21^{\circ} \mathrm{C}$ and $\mathrm{a} 31 \%$ and $41 \%$ drop in strength was observed in the range $3^{\circ} \mathrm{C}$ to $5^{\circ} \mathrm{C}$ and $37^{\circ} \mathrm{C}$ to $39^{\circ} \mathrm{C}$ respectively. Statistical analysis of strength at ambient temperatures between $5^{\circ} \mathrm{C}$ to $40^{\circ} \mathrm{C}$ dry bulb values gave a second order "inverted-U" relationship between strength and temperature and, a second order " $U$-shaped" relationship between the drop in strength and temperature

KEYWORDS: Physical Strength, Push, Pull, Pedal, Grip, Heat Stress \& Cold Stress
\end{abstract}

Received: Apr 06, 2019; Accepted: Apr 26, 2019; Published: May 23, 2019; Paper Id.: IJMPERDJUN2019120

\section{INTRODUCTION}

Global warming aggravated due to increased greenhouse gas emissions represents a threat to human life. Lethal heat waves due to ongoing climate change are also predicted to occur more frequently ${ }^{1}$. Working in these extreme temperatures will require a complete overhaul of the current globally adopted systems of work measurement, work severity, and postural analysis. At present, most standard work measurement techniques do not account for the impact of environmental variables like temperature on the work content analysis and the number of persons required for the given quantum of work. In industries as well as in the unorganized sector, variations in thermal conditions due to seasonal changes are not considered while determining standard output level for the labor and for assessment of human resource requirement. It is therefore imperative that studies on the impact of heat and cold stress on working capacity be carried out and existing guidelines be modified. Kjellström ${ }^{2}$ has suggested that climate change is expected to become severe and each country is recommended to develop a local occupational health impact analysis and prevention plan to protect workers' health.

Environmental conditions in which work is performed are usually considered out of the scope of most research work, although their general impact is well known. In industries as well as in the unorganized sector, variations in thermal conditions due to seasonal changes are not considered while determining standard output level for the labor and for assessment of human resource requirement. 
There is only a very small amount of literature reviewing the effects of cold temperatures on physical strength. A gradual loss of manual dexterity is experienced with the decline in the temperature of various physiological structures including skin, muscle, receptor, nerve, and joint temperatures. De Jong et al. ${ }^{3}$ observed that there is a reduction in nerve conduction velocity that drops strongly at a nerve temperature below $20^{\circ} \mathrm{C}$ and is effectively blocked at $10^{\circ} \mathrm{C}$. Strength and sustainability are also affected by declining temperatures. In the cold series of experiments conducted by Meese et al. ${ }^{4}$ finger strength and speed and manual dexterity on an assembly line taskwere found to be decreased as the temperature fell from $24^{\circ} \mathrm{C}$ through $18^{\circ} \mathrm{C}, 12^{\circ} \mathrm{C}$ to $6^{\circ} \mathrm{C}$.

The effects of thermal environments on the risks associated with manual handling were also studied in a research report by S Powell ${ }^{5}$ for the Health and Safety laboratory. Studies were done at two thermal environments namely, cold environment $0^{\circ} \mathrm{C}$ to $10^{\circ} \mathrm{C}$ and hot environment $29^{\circ} \mathrm{C}$ to $39^{\circ} \mathrm{C}$. The authors recommended that decreasing lifting frequency in hot environments would help in reducing the extra physiological strain imposed by hot thermal environments.

Furtado et al. ${ }^{6}$ studied the effect of heat stress on physiological effects and task performance and found that simple tasks were less effected by heat stress compared to complex tasks such as tracking, monitoring, and multiple tasks. Kamon \& Belding ${ }^{7}$ assessed the physiological cost of carrying loads in temperate and hot environments. The authors observed an increased heart rate at elevated temperatures due to heat stress. Snook \& Ciriello ${ }^{8,9}$ investigated the effects of heat stress on lifting, pushing and carrying tasks using a sample of sixteen male industrial workers. Two environments were studied, moderate $\left(17.2^{\circ} \mathrm{C}\right.$ WBGT $)$ and hot $\left(27^{\circ} \mathrm{C}\right.$ WBGT). It was found that in the hot environment, the self selected workload was significantly reduced by $20 \%$ for the lifting task and that heart rate was significantly increased by 9 - 10 beats. $\min ^{-1}$. A similar methodology was used by Hafez \& Ayoub ${ }^{10}$ for testing six male subjects who performed a lifting test similar to that described by Snook \& Ciriello. At a frequency of 3 lifts. $\min ^{-1}$ there was an $18.3 \%$ reduction in weight lifted between $27^{\circ} \mathrm{C}$ and $32^{\circ} \mathrm{C}$. At 6lifts. $\min ^{-1}$ there was a $21.5 \%$ decrease in weight lifted. The authors suggested that individuals working in hotter environments (specifically $32^{\circ} \mathrm{C}$ WBGT) should reduce the weight of the load lifted and take longer rest periods.

S.A.Yildizel, et al. ${ }^{11}$ assessed the impact of heat stress on performance and worker health at a construction site in Moscow. Temperatures were varied between 16 to 23 degrees centigrade in two sets of experiments involving more than 193 workers. No specific quantification of the impact of temperature on work severity, in general, was established. Matt Brearley et al. ${ }^{12}$ undertook a study of electrical utility workers in the northern territory of Australia to examine their physiological and fluid balance responses to climatic conditions. Authors recommended more studies to extend the impact on broader occupational settings.

Jeremiah Chinnadurai et al. ${ }^{13}$ undertook a study of construction workers in Chennai, India to estimate the productivity in construction work under the influence of heat stress using the Predictive Mean Vote (PMI) index. Their study showed that working outdoors had a significant adverse impact on productivity to the extent of $35 \%$.

Galloway and Maughan ${ }^{14}$ demonstrated an 'inverted-U' relationship between ambient temperature and submaximal exercise tolerance time, with a peak at $10.5^{\circ} \mathrm{C}$ and equivalent decreases at $3.6^{\circ} \mathrm{C}$ and $20.6^{\circ} \mathrm{C}$, with a further impairment at $30.5^{\circ} \mathrm{C}$. Ramsey et al. ${ }^{15}$ found that temperatures below and above those typically preferred by most people had a significantly detrimental effect on the safety-related behavior of workers. Similarly, Tawatsupa $\mathrm{B}^{16}$ observed a strong association between heat stress and occupational injury. Dunne et $a l^{17}$ found a reduction in labor capacity due to heat stress. 
Stephen S Cheung et al. ${ }^{18}$, have reviewed the effect of thermal stress, human performance and physical employment standards. The review surveys the major occupational impact of thermal extremes and existing employment standards, proposing guidelines for improvement and areas for future research.

Priya Dutta, et al. ${ }^{19}$ assessed the impact of heat on the health of construction workers in Ahmedabad, Gujarat. The assessment was a combination of survey questionnaires, focused group discussion, and onsite temperature measurements. No quantitative relationship between temperature and work severity was established. Authors suggested that further studies estimating the exact nature of thermal loads experienced by construction workers were essential for the long term benefit of these workers.

From the literature reviewed, the lack of sufficient research into the direct effects of the thermal environment on manual handling tasks is apparent and more studies are required to assess the impact of temperature on physical capability. Hence, it was decided to evaluate the impact of heat and cold stress on human strength.

\section{EXPERIMENTAL DETAILS}

Laboratory experimentation on 99 human subjects (volunteers) under varying temperature conditions was done in order to assess the effect of changing the temperature on strength of the subjects. A physically fit subject (pre-cleared by physician) was asked to sit in the controlled environment for about 30 minutes for acclimatization, after which he underwent the strength tests. The subject executed a standard test protocol on a dynamometer during which average value of push strength applied for a period of 30 seconds was obtained. Similarly, the average value of pull strength, pedal strength, and grip strength were obtained using corresponding dynamometers. The temperature was varied and the subject underwent the same standard test protocol at six different temperatures, namely, $5^{\circ} \mathrm{C}, 10^{\circ} \mathrm{C}, 20^{\circ} \mathrm{C}, 25^{\circ} \mathrm{C}, 30^{\circ} \mathrm{C}$ and $40^{\circ} \mathrm{C}$ (dry bulb temperature). Humidity was not controlled but recorded for every test. The collected data was analyzed to assess and quantify the relationship between environmental conditions and strength. Statistical correlation analysis using Excel was carried out to quantify the effect of ambient conditions on strength.

\section{RESULTS AND DISCUSSION}

\section{Studies on the Effect of Ambient Dry Bulb Temperature on Physical Strength}

The push, pull, pedal and grip strength of subjects were obtained at different ambient dry bulb temperatures for this study. Due to physical attributes, there was a large variation in maximum strength exerted by individuals. Since the focus of the current research was to study the effect of temperature on human strength it was decided to normalize the strength values. For this, the actual minimum strength recorded of an individual at a given temperature was converted to unity (1.0) and strengths of the same individual at other ambient temperatures were obtained by normalization. The average of normalized push, pull, and pedal and grip strength of all the 99subjects versus temperature is given in Table1. It was observed that peak strength in all cases was at $20^{\circ} \mathrm{C}$ or $25^{\circ} \mathrm{C}$. 
Table 1: Temperature Vs. Normalized Average Push, Pull, Pedal and Grip Strength

\begin{tabular}{|c|c|c|c|c|}
\hline Temperature & $\begin{array}{c}\text { Normalized } \\
\text { Average Push } \\
\text { Strength }\end{array}$ & $\begin{array}{c}\text { Normalized } \\
\text { Average Pull } \\
\text { Strength }\end{array}$ & $\begin{array}{c}\text { Normalized } \\
\text { Average Pedal } \\
\text { Strength }\end{array}$ & $\begin{array}{c}\text { Normalized } \\
\text { Average Grip } \\
\text { Strength }\end{array}$ \\
\hline 5 & 1.1424 & 1.2237 & 1.1506 & 1.1539 \\
\hline 10 & 1.3363 & 1.4452 & 1.3588 & 1.3762 \\
\hline 20 & 1.5872 & 1.7568 & 1.5638 & 1.6000 \\
\hline 25 & 1.6146 & 1.8047 & 1.6091 & 1.5992 \\
\hline 30 & 1.2964 & 1.3200 & 1.3328 & 1.2548 \\
\hline 40 & 1.0656 & 1.0592 & 1.1103 & 1.0394 \\
\hline
\end{tabular}

The statistical analysis gave a second order "inverted-U" relationship between strength which is the dependent variable and temperature the independent variable is obtained (Figure 1 to Figure 4). The smooth line indicates the curve given by the regression equation and the plot indicates curve from the actual data.

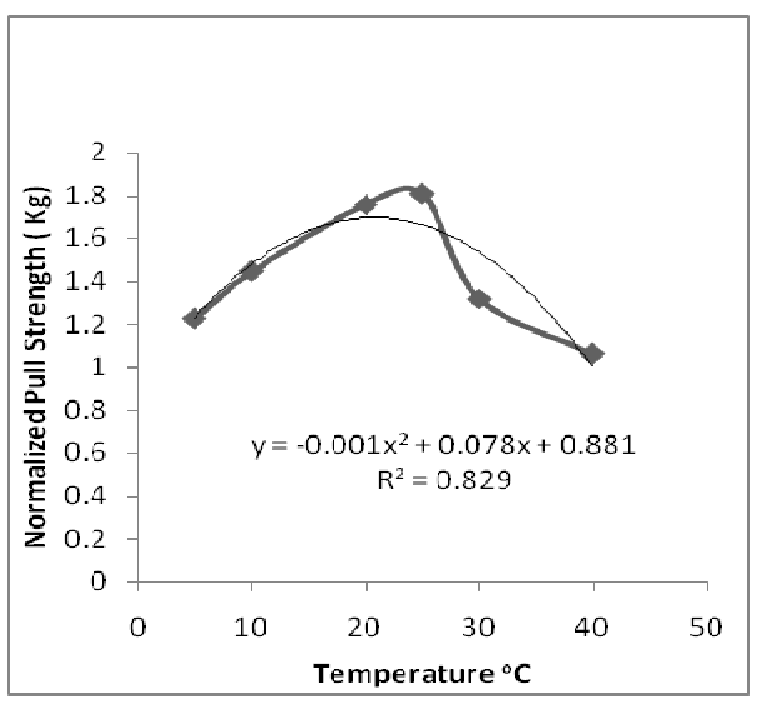

Figure 1: Normalized Average Push Strength vs. Temperature

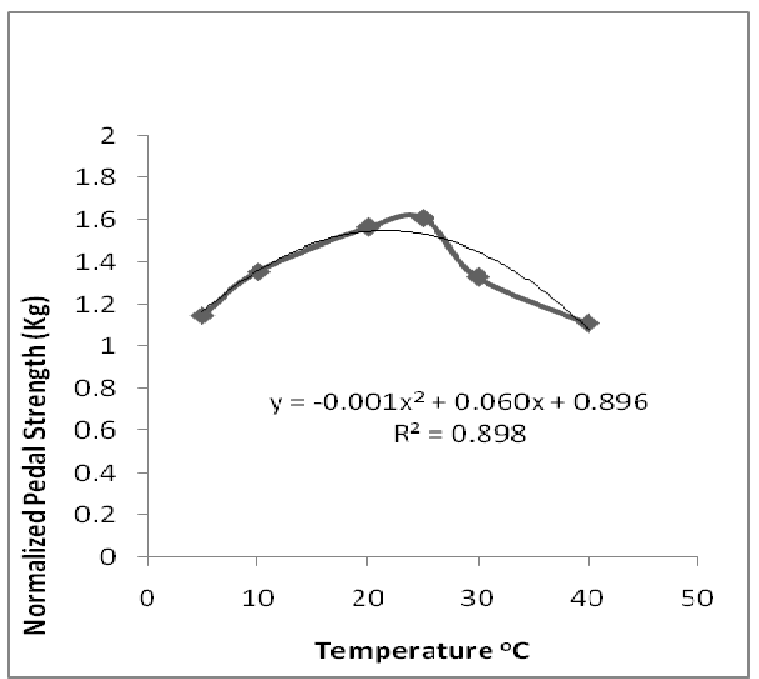

Figure 3: Normalized Average Pedal Strength vs. Temperature

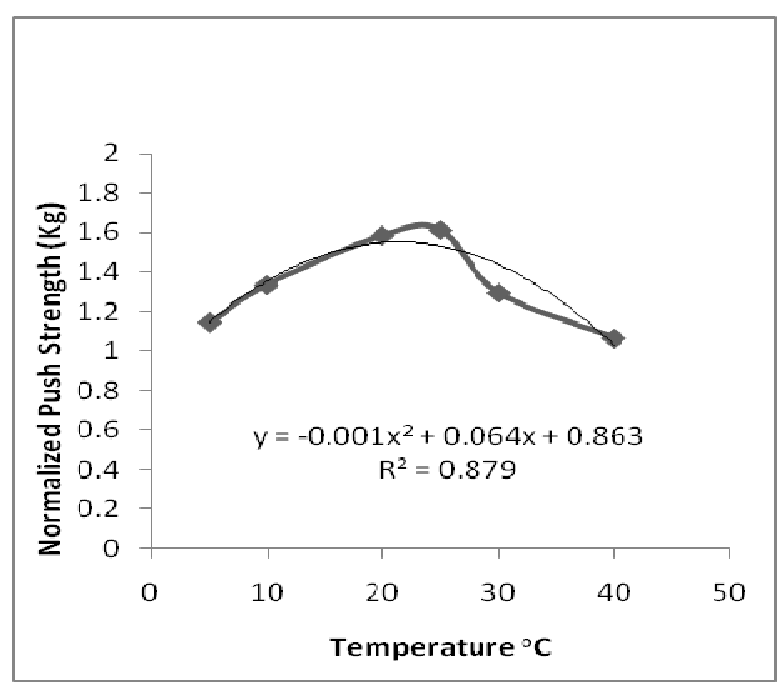

Figure 2: Normalised Average Pull Strength vs Temperature

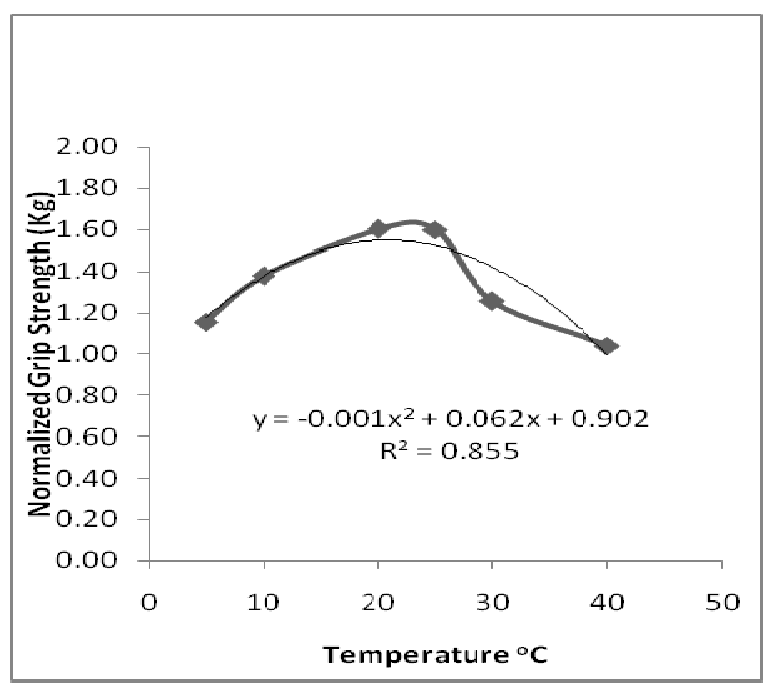

Figure 4: Normalised Average Grip Strength vs.Temperature 


\section{Studies on Percentage Drop in Strength}

As the relationship between strength and temperature was found to be an "inverted - $U$ ", it was decided to find out the percentage drop in strength at the two extreme temperatures. Earlier studies by researchers ${ }^{8,20}$ had found a $21.5 \%$ decrease in weight lifted and 35\% adverse impact on productivity, respectively under the influence of heat stress. To quantify the drop in strength with temperature, the maximum strength of the subject was found and the percentage drop in strength at the two extremes, namely, $5^{\circ} \mathrm{C}$ and $40^{\circ} \mathrm{C}$ were calculated. This is shown in Table 2.

Table 2: Percentage Average Drop in Strength at $5^{\circ} \mathrm{C}$ and $40^{\circ} \mathrm{C}$

\begin{tabular}{|l|c|c|}
\hline \multicolumn{1}{|c|}{ Strength } & $\begin{array}{c}\text { \% Average Drop in } \\
\text { Strength at } \mathbf{5}^{\mathbf{0}}\end{array}$ & $\begin{array}{c}\text { \% Average Drop in } \\
\text { Strength at } \mathbf{4 0}^{\mathbf{0}} \mathbf{C}\end{array}$ \\
\hline Push strength & 29.66 & 34.03 \\
\hline Pull strength & 32.56 & 40.91 \\
\hline Pedal strength & 28.88 & 31.07 \\
\hline Grip strength & 30.44 & 37.16 \\
\hline $\begin{array}{l}\text { Average of push, pull, } \\
\text { pedal, grip }\end{array}$ & 30.38 & 35.79 \\
\hline
\end{tabular}

An average drop across push, pull, pedal and grip strength of $30.38 \%$ was observed at $5^{\circ} \mathrm{C}$ and of $35.79 \%$ at $40^{\circ} \mathrm{C}$. It was also observed that out of all the strength measurements the highest drop in strength is observed for pull strength, which may probably be due to the nature of the task being against gravity.

A similar procedure was used to find the percentage drop in strength at all temperatures studied between $5^{\circ} \mathrm{C}$ and $40^{\circ} \mathrm{C}$ and is represented graphically in Figures 5 to 8 below.

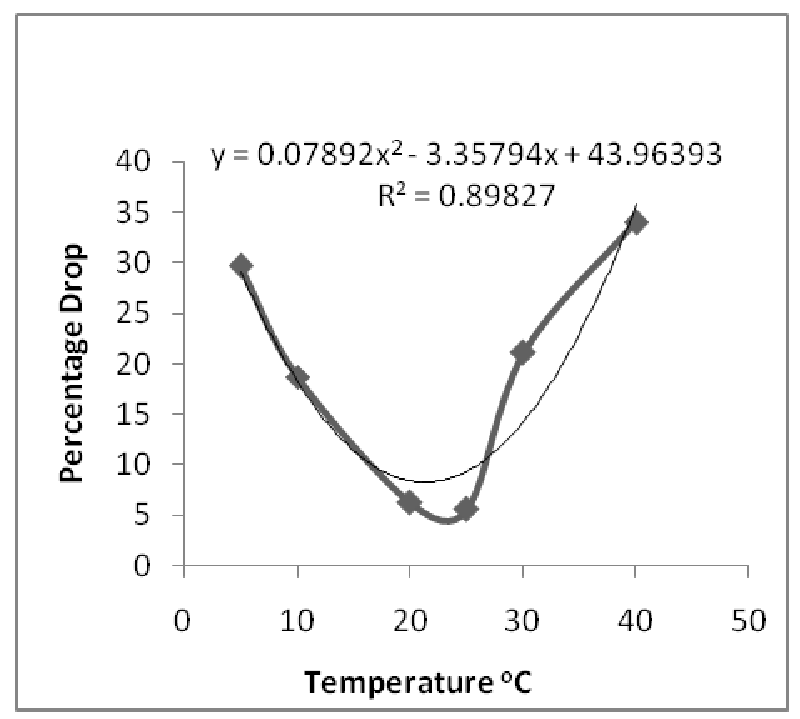

Figure 5: Percentage Drop in Strength - Push Force

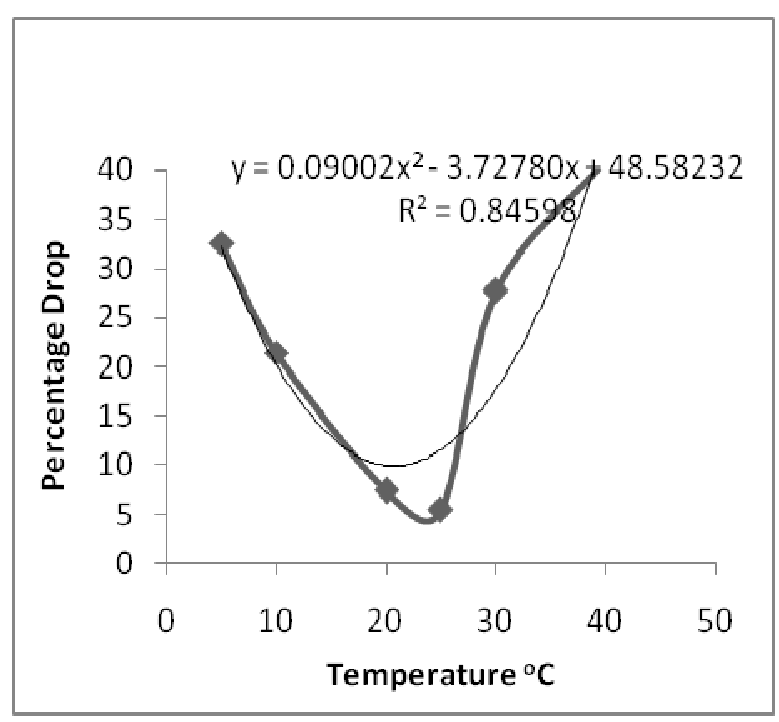

Figure 6: Percentage Drop in Strength - Pull Force 


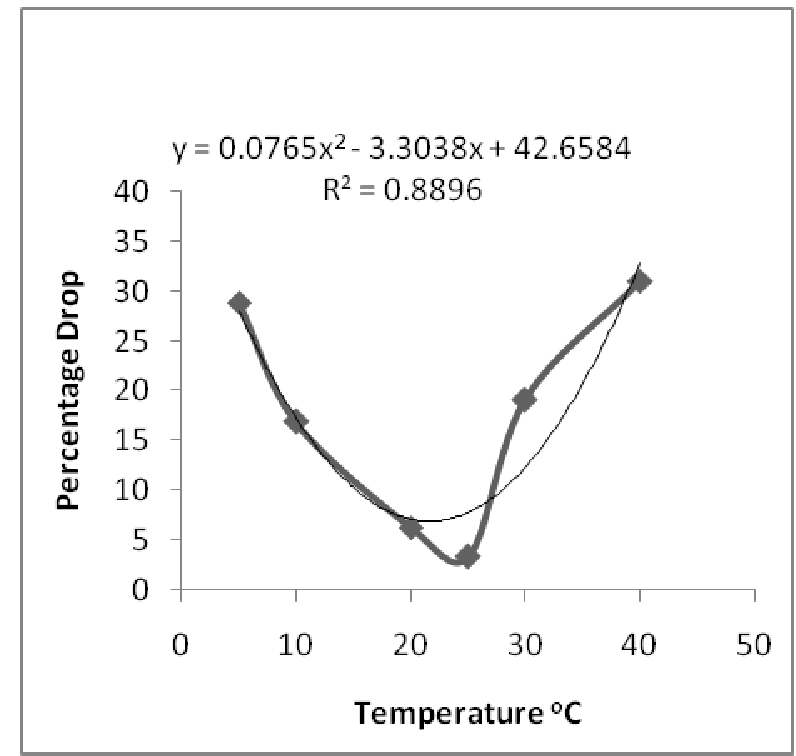

Figure 7: Percentage Drop in Strength Pedal Force

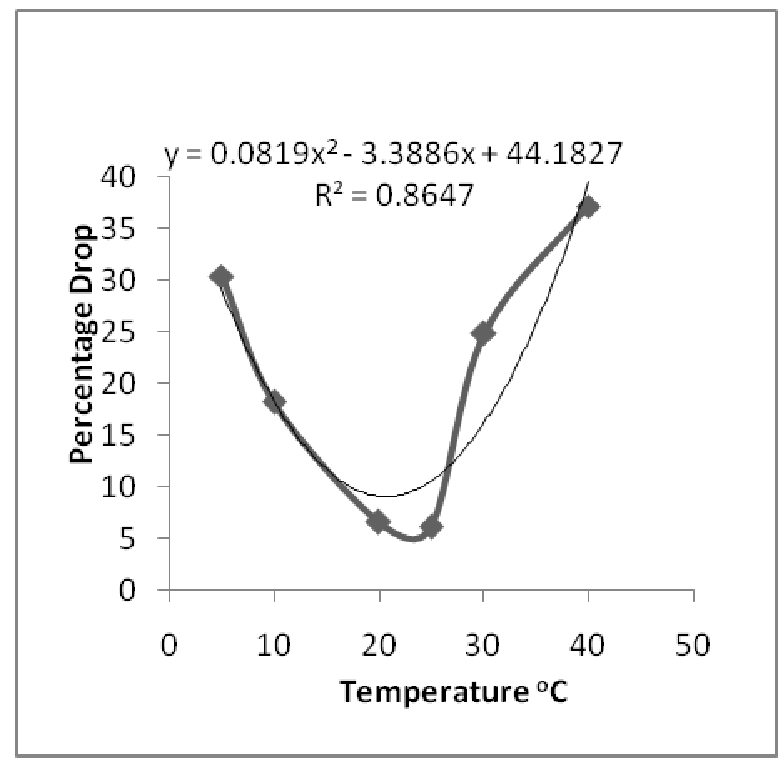

Figure 8: Percentage Drop in Strength Grip Force

Regression analysis of the correlation between percentage drop in strength and ambient temperature was done and is also represented in Figure 5 to Figure 8. The equations obtained in these four graphs may be used to determine percentage drop in strength at any temperature between $5^{\circ} \mathrm{C}$ and $40^{\circ} \mathrm{C}$ for push, pull, pedal or grip strength for an individual. Application of these drop in strength values in daily workload allocation may result in reducing worker's health issues.

\section{Studies on the Effect of wet Bulb Globe Temperature (WBGT) on Physical Strength}

When the push, pull, pedal and grip strength of subjects was being measured at different ambient dry bulb temperatures, existing humidity values were also recorded. The airspeed in the lab was observed to be $0.5 \mathrm{~m} / \mathrm{s}$ at all times. From the humidity, dry bulb temperature and airspeed values the corresponding WBGT (indoor) values were obtained using Excel Heat Stress calculator ${ }^{21}$. As humidity was not controlled and existing values of humidity at given dry bulb temperature were used to obtain WBGT, a uniformity in WBGT values for all 99 subjects was not possible to achieve. Therefore the WBGT values were sorted into class intervals and strength values in the interval were averaged. Results are shown in Table 3. It is seen that the maximum push strength and pull strength was observed in the class $15^{\circ} \mathrm{C}$ to $17^{\circ} \mathrm{C}$ WBGT, maximum pedal strength in the class $19^{\circ} \mathrm{C}$ to $21^{\circ} \mathrm{C} \mathrm{WBGT}$, and maximum grip strength in the class $13^{\circ} \mathrm{C}$ to $15^{\circ} \mathrm{C}$ WBGT.

Table 3: WBGT (Indoor) Vs. Normalized Average Push, Pull, Pedal and Grip Strength

\begin{tabular}{|c|c|c|c|c|}
\hline WBGT ${ }^{\mathbf{0}} \mathbf{C}$ & $\begin{array}{c}\text { Average of Push } \\
\text { Strength Values }\end{array}$ & $\begin{array}{c}\text { Average of Pull } \\
\text { Strength Values }\end{array}$ & $\begin{array}{c}\text { Average of Pedal } \\
\text { Strength Values }\end{array}$ & $\begin{array}{c}\text { Average of Grip } \\
\text { Strength Values }\end{array}$ \\
\hline $3-5$ & 1.1576 & 1.2244 & 1.1390 & 1.1664 \\
\hline $7-9$ & 1.3200 & 1.4460 & 1.3704 & 1.4308 \\
\hline $9-11$ & 1.3270 & 1.4282 & 1.4148 & 1.3912 \\
\hline $13-15$ & 1.4026 & 1.6808 & 1.4742 & 1.7287 \\
\hline $15-17$ & 1.6945 & 1.7825 & 1.5657 & 1.5801 \\
\hline $17-19$ & 1.5137 & 1.7351 & 1.6152 & 1.7273 \\
\hline $19-21$ & 1.5609 & 1.6911 & 1.6683 & 1.4660 \\
\hline $21-23$ & 1.4559 & 1.4373 & 1.6029 & 1.5368 \\
\hline $23-25$ & 1.4696 & 1.6382 & 1.4577 & 1.3824 \\
\hline $25-27$ & 1.3169 & 1.2830 & 1.4496 & 1.4401 \\
\hline
\end{tabular}




\begin{tabular}{|l|l|l|l|l|}
\hline $27-29$ & 1.2088 & 1.2827 & 1.2301 & 1.1987 \\
\hline $29-31$ & 1.1050 & 1.1857 & 1.1416 & 1.1176 \\
\hline $31-33$ & 1.0975 & 1.1225 & 1.1689 & 1.0585 \\
\hline $33-35$ & 1.0588 & 1.0444 & 1.0891 & 1.0232 \\
\hline $35-37$ & 1.0327 & 1.0214 & 1.0726 & 1.0204 \\
\hline $37-39$ & 1.0000 & 1.0000 & 1.0063 & 1.0362 \\
\hline
\end{tabular}

Figure 9 to 12 show the bar chart with a trend line of WBGT classes versus the strength values. In all cases (push, pull, pedal and grip strength) it is observed that there was a substantial drop in strength at extremes (temperature class $3{ }^{\circ} \mathrm{C}$ to $5^{\circ} \mathrm{C}$ and $37^{\circ} \mathrm{C}$ to $39^{\circ} \mathrm{C}$ WBGT) compared to the peak strength value. To quantify the drop in strength at the two extremes of WBGT classes, the maximum strength exerted by the subject was taken and percentage drop from this value at lowest $\left(3^{\circ} \mathrm{C}\right.$ to $\left.5^{\circ} \mathrm{C}\right)$ and highest $\left(37^{\circ} \mathrm{C}\right.$ to $\left.39^{\circ} \mathrm{C}\right)$ WBGT class intervals were calculated. This is shown in Table 4. It is found that average drop across push, pull, pedal and grip strength of $31.81 \%$ was obtained for $3{ }^{\circ} \mathrm{C}$ to $5^{\circ} \mathrm{C}$ WBGT class and $41.15 \%$ was obtained for $37^{\circ} \mathrm{C}$ to $39^{\circ} \mathrm{C}$ WBGT class.

Table 4: Percentage Average Drop in Strength at 3oc to 5oc and 37oc to 39oc WBG

\begin{tabular}{|l|c|c|}
\hline \multicolumn{1}{|c|}{ Strength } & $\begin{array}{c}\text { \% Average Drop in } \\
\text { Strength at } \mathbf{3}^{\mathbf{0}} \mathbf{C} \text { to } \mathbf{5}^{\mathbf{0}} \mathbf{C} \\
\text { WBGT }\end{array}$ & $\begin{array}{c}\text { \% Average Drop in } \\
\text { Strength at } \mathbf{3 7}^{\mathbf{0}} \mathbf{C} \text { to } \mathbf{3 9}^{\mathbf{0}} \mathbf{C} \\
\text { WBGT }\end{array}$ \\
\hline Push strength & 31.68 & 40.98 \\
\hline Pull strength & 31.30 & 43.89 \\
\hline Pedal strength & 31.72 & 39.68 \\
\hline Grip strength & 32.52 & 40.05 \\
\hline
\end{tabular}

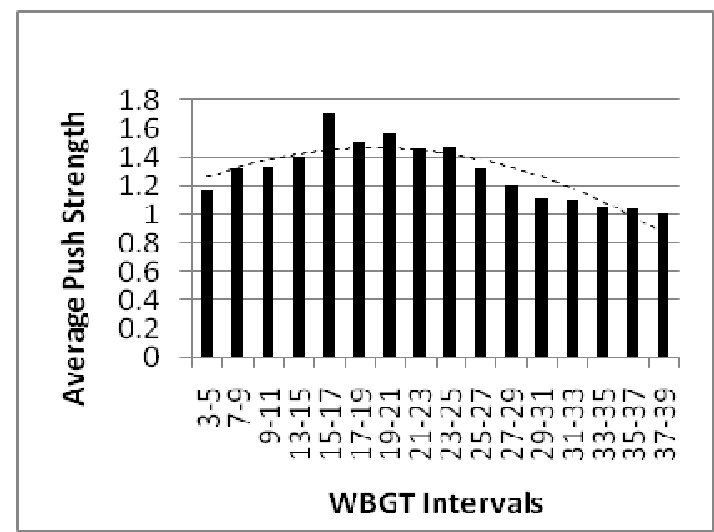

Figure 9: Average Push Strength Vs WBGT

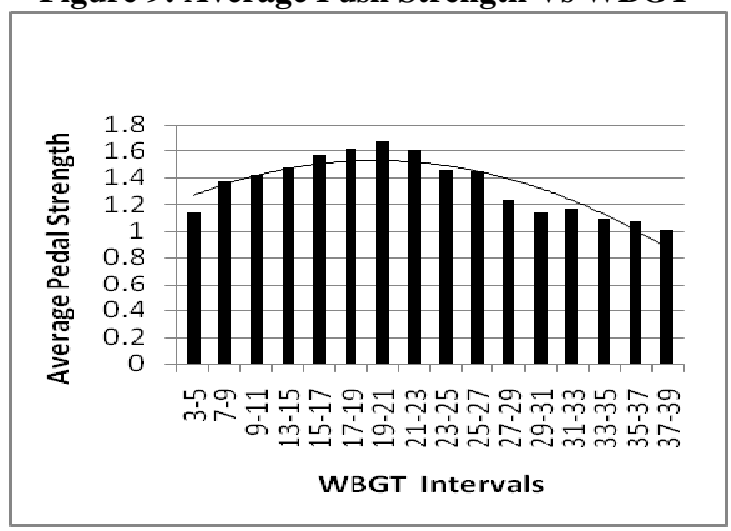

Figure 11: Average Pedal Strength Vs WBGT

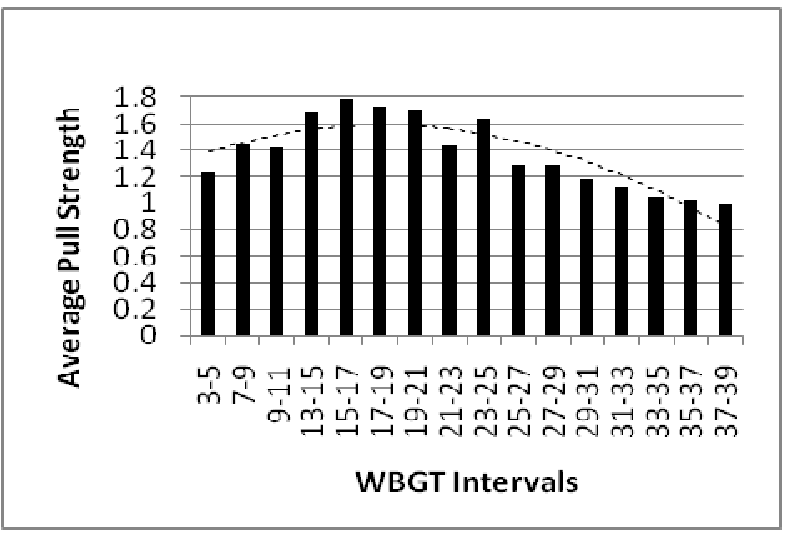

Figure 10: Average Pull Strength Vs WBGT

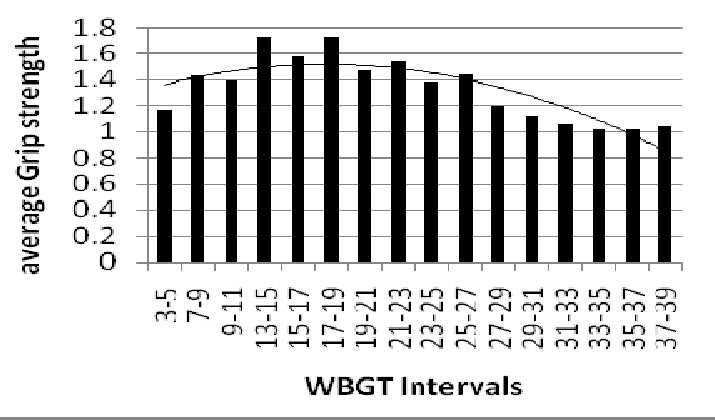

Figure 12: Average Grip Strength Vs WBGT 


\section{CONCLUSIONS}

In both the dry bulb temperature and WBGT studies it was observed that subjects gave peak performance within comfortable ambient conditions, namely, at dry bulb temperatures of $20^{\circ} \mathrm{C}$ to $25^{\circ} \mathrm{C}$ and $13^{\circ} \mathrm{C}$ to $21^{\circ} \mathrm{C}$ of WBGT. A decrease in strength was observed at both higher and lower temperatures. The percentage average drop in strength at a low range of temperatures was similar in case of dry bulb and WBGT i.e.,30.38\% and $31.81 \%$ (Table 2 and Table 4) respectively. However, a much greater percentage drop in the strength of $41.15 \%$ was observed at $37^{\circ} \mathrm{C}$ to $39^{\circ} \mathrm{C}$ WBGT (Table 4 ) in comparison to a drop in the strength of $35.79 \%$ at $40^{\circ} \mathrm{C}$ dry bulb temperature (Table 2). Closer examination of Table 3 shows the lowest strengths among WBGT classes above $33^{\circ} \mathrm{C}$. All these classes corresponded to $40^{\circ} \mathrm{C}$ dry bulb temperature and humidity values of greater than $50 \%$. It can be concluded that the effect of humidity on strength becomes pronounced at temperatures above the $30^{\circ} \mathrm{C}$ dry bulb and should not be ignored in work content calculations.

In the case of dry bulb temperature studies, a second order "U-shaped" relationship was obtained between the percentage drop in strength and temperature. This equation may be used to predict a drop in strength at any given temperature. However, based on conclusions drawn from the comparison above, while applying this equation above $30^{\circ} \mathrm{C}$ dry bulb temperature and greater than $50 \%$ humidity, an additional drop in strength due to the effect of humidity also needs to be factored into the work content calculations.

\section{REFERENCES}

1. Mora C, Dousset B, Caldwell IR et al. (2017) Global risk of deadly heat. Nature Climate Change. 7(7): 501-506.

2. Kjellström T, Briggs D, Freyberg C, Lemke B, Otto M, Hyatt O (2016) Heat, human performance and occupational health: a key issue for the assessment of global climate change impacts. Annu. Rev. Public Health. 37: 97-112.

3. De Jong RH, Hershey WN, Wagman IH, . (1966)Nerve conduction velocity during hypothermia in man, Anesthesiology, 27(6):805-10

4. Meese, G.B., Kok, R., Lewis, M.I. and Wyan, D.P. (1984) A laboratory study of the effects of moderate thermal stress on the performance of factory workers, Ergonomics, 27, 1, 19-43.

5. S Powell (2005)The effects of thermal environments on the risks associated with manual handling S. Powell PhD, BSc (Hons) A. Davies BSc (Hons) MSc J. Bunn BSc, MSc D. Bethea BSc (Hons) research Report 337, Prepared by The Health and Safety Laboratory

6. Alwyn L. Furtado, Brian N. Craig, Joshua T., ChardVictor A. Zaloom and Hsing-Wei Chu, (2007)Cooling Suits, Physiological Response and Task Performance in Hot Environments for the Power Industry, International Journal of Occupational Safety and Ergonomics (JOSE), Vol. 13, No. 3, 227-239.

7. Kamon, E., \& Belding, H.S. (1971). The physiological cost of carrying loads in temperate and hot environments. Human Factors, 13, (2), $153-161$.

8. Snook, S.H., \& Ciriello, V.M. (1974). The effects of heat stress on manual handling tasks. American Industrial Hygiene Association Journal, 35, 681 - 685.

9. Snook, S.H., \& Ciriello, V.M. (1991). The design of manual handling tasks: revised tables of maximum acceptable weights and forces. Ergonomics, 34, (9), 1197-1213.

10. Hafez, H.A., \& Ayoub, M.M. (1991). A psychophysical study of manual lifting in hotenvironments. International Journal of Industrial Ergonomics, 7, 303 - 309. 
11. S.A.Yildizel, G.Kaplan, et al, (2015) A study on the effects of weather conditions on the worker health and performance in a construction site, Journal of Engineering Research and Applied Science, Volume 4(1), June, pages 291-295

12. Matt Brearley, Phillip Harrington, et al, (2014), Working in Hot Conditions - A Study of Electrical Utility Workers in The Northern Territory of Australia, Journal of Occupational and Environmental Medicine, Vol 12, pages 156-163

13. Jeremiah Chinnadurai, VidhyaVenugopal, et al,(2016)Influence of occupational heat stress on labor productivity - a case study from Chennai, India, International Journal of Productivity and Performance Management, Vol 65, Issue 2, pages 245 - 255

14. Galloway, S. and Maughan, R.J. (1997) Effects of Ambient Temperature on the Capacity to Perform Prolonged Cycle Exercise in Man. Medicine and Science in Sports and Exercise, 29, 1240-1249.

15. Ramsey JD, Burford CL, Beshir MY, Jensen RC (1983) Effects of workplace thermal conditions on safe work behaviour. J. Safety Research. 14: 105-114.

16. Tawatsupa B, Yiengprugsawan V, Kjellstrom T, Berecki-Gisolf J, Sebsman SA, Sleigh A (2013) Association between heat stress and occupational injury among Thai workers: findings of the Thai Cohort Study. Industrial Health. 51: 34-46.

17. Dunne JP, Stouffer RJ, John J (2013) Reductions in labour capacity from heat stress under climate warming. Nature Climate Change. 3: 563-566.

18. Stephen S. Cheung, Jason K.W. Lee, Juha Oksa, (2016) Thermal stress, human performance and physical employment standards, Applied Physiology, Nutrition, and Metabolism, Appl. Physiol. Nutr. Metab. 41: S148-S164

19. Priya Dutta, AjitRajiva, et al, (2015)Perceived heat stress and health effects on construction workers, Indian Journal of Occupational and Environmental Medicine, Vol. 19, Issue 3 pages 151-158

20. Venugopal V, Chinnadurai JS, Lucas R, Kjellström T (2016) Occupational heat stress profile in selected workplaces in India. Int. J. Environ. Research and Public Health. 13(89). 21) http://www.climatechip.org/excel-wbgt-calculator 
